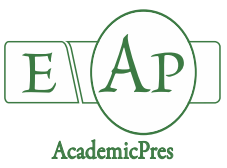

Jovanovic Todorovic M et al. (2020)

Notulae Botanicae Horti Agrobotanici Cluj-Napoca 48(3):1495-1503

DOI: $10.15835 /$ nbha48312057

Research Article

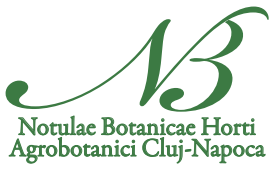

\title{
Impact of row spacing and seed rate on the production characteristics of the perennial ryegrass (Lolium perenne L.) and their valorisation
}

\author{
Marijana JOVANOVIĆ TODOROVIĆ ${ }^{1}$, Vera POPOVIĆ ${ }^{2 *}$, \\ Savo VUČKOVIĆ 3 , Snežana JANKOVIĆ ${ }^{4}$, Andreja MIHAILOVIĆ , $^{2}$ \\ Maja IGNJATOV ${ }^{2}$, Vladimir STRUGAR ${ }^{2}$, Velimir LONČAREVIĆ ${ }^{2}$ \\ ${ }^{1}$ Institute of Agricultural Economist, 15 Volgina, 11000, 11000 Belgrade, Serbia; marijanajovanovic@gmail.com \\ ${ }^{2}$ Institute of Field and Vegetable Crops,30 Maksim Gorky Street, 21000, Novi Sad, \\ Serbia;drvvpopovic@gmail.com (*correspondingauthor);maja.ignjatov@ifvcns.ns.ac.rs; \\ vladimirstrugar75@gmail.com; velimir.loncarevic@ifvcns.ns.ac.rs \\ ${ }^{3}$ University of Belgrade, Faculty of Agriculture,6 Nemanjina Street, 11120, Belgrade, Serbia; savovuck@agrif.bg.ac.rs \\ ${ }^{4}$ Institute of Applied Science in Agriculture,68 B. Despota Stefana, 11000, Belgrade, Serbia; sjankovic@ipn.bg.ac.rs \\ ${ }^{5}$ UNION University, Faculty of Law, 36 B. Maršala Tolbuhina, 11000, Belgrade, Serbia; deamihailovic@gmail.com
}

\begin{abstract}
In this paper are shown the results of the production characteristics of the perennial ryegrass (Lolium perenne L.) cv. 'Naki', which grown in rows with different row spacing and seed rate in the agroecological conditions of central Serbia in three successive analysed years. Four levels of two observed factors were used in the experiment: row spacing $(12.5 ; 25 ; 37.5$ and $50 \mathrm{~cm})$ and seed rate $\left(9,16,23\right.$ and $\left.30 \mathrm{~kg} \mathrm{ha}^{-1}\right)$. Due to the analyses, the height of the tiller, the length of the spike and the number of spikelets per spike gave better results by sowing in wider rows $(37.5$ and $50 \mathrm{~cm})$ using lower seed rate $\left(9\right.$ and $\left.16 \mathrm{~kg} \mathrm{ha}^{-1}\right)$. Seed yield and harvest index responded favourably to sowing in rows at a wider row spacing $(37.5$ and $50 \mathrm{~cm})$ in combination with a lower seed rate ( 9 and $\left.16 \mathrm{~kg} \mathrm{ha}^{-1}\right)$, while shoot dry weight gave better results by sowing in narrower rows $(12.5 \mathrm{~cm})$ with lower seed rate $\left(9\right.$ and $\left.16 \mathrm{~kg} \mathrm{ha}^{-1}\right)$. Using the appropriate row spacing in sowing and the optimum of seed rate provides the highest results of the production characteristics of the perennial ryegrass that can be applied to further production.
\end{abstract}

Keywords: harvest index; perennial ryegrass; row spacing; seed rate; seed yield

\section{Introduction}

Perennial ryegrass (Lolium perenneL.), from an agronomic point of view, represent the most important grassland type for pasture in temperate climates and it is the most important type in the genus Lolium (Bolaric et al., 2005). It is a native plant type in Europe from where is widespread to North America, Africa and Australia. In Serbia, it is known as one of the best forage species (Tomić et al., 2007), characterized by high nutritional value and therefore can be used for grazing as well as for hay or silage. It is reported that Perennial ryegrass has been cultivated as a forage species since the 17th century (Grime et al., 1988). Additionally, Perennial ryegrass shows a high degree of genetic variation in the population (Kubik et al., 2001), which is very 
important considering diploid varieties are still the majority of seed sown in the world (Dalton, 1998). Signification of perennial ryegrass as an animal feed derives primarily from its high digestibility and dry matter quality (Frame, 1989), it is well tolerated in stepping and responds well to nitrogen fertilization. In our country, Perennial ryegrass breeders are driven by market needs to produce genotypes with high, stable yields and excellent dry matter quality with improved impedance as well as drought impedance (Sokolović et al., 2012). One of the most important factors of the cultivation process, in addition to creating frost-resistant varieties and the impact of other environmental factors, is the yield and quality of the seed. Important characteristics for cultivation are flowering date, the length of the spike, the number of spikelets per spike, due to their high variability and heritability.

The agro-ecological conditions of the locality are very important factor defining seed production (Gatarić, 2005; Koeritz, 2012; Jamil et al., 2017; Janković et al., 2018; Lakić et al., 2018; 2019; Bojović et al., 2019). Research shows that row spacing has a significant impact on seed yield. The highest seed yield can be achieved by sowing seeds at a distance of $20 \mathrm{~cm}$ (Vučković et al., 1998), as well as by sowing at distances of 25 $\mathrm{cm}$ (Fišakov, 1984) or 45-60 cm distances in some very dry areas of Turkey (Uzun and Acikgoz, 1998). Interacting in sowing with a different seed rate from 2.8 to $8.4 \mathrm{~kg} \mathrm{ha}^{-1}$ with a wider spacing between rows $(30.5$ $\mathrm{cm})$ and a greater amount of nitrogen $\left(157 \mathrm{~kg} \mathrm{ha}^{-1}\right)$, the Perennial ryegrass responded by increasing the seed yield (Koeritz, 2012). In some parts of Canada, sowing seeds of $8-10 \mathrm{~kg} \mathrm{ha}^{-1}$ at a row spacing of 15 to $30 \mathrm{~cm}$ has produced great results (Cattani, 2007).

The subject of this paper is using the results of previous research and the results of this research to improve the potential of grass seed production in the agro ecological conditions of central Serbia. The potential for development is based on the proper combination of row spacing and seed rate in a particular locality and in a particular environment which impact on the correlation between stages during the vegetative development of the flowering plants and following the seed yields depends on many factors.

\section{Materials and Methods}

\section{Plant material}

The research was conducted over three following years, between 2012-2014 in the terrain and in the laboratory. The terrain experiment was located near Arandjelovac $\left(44^{\circ} 21^{\prime} \mathrm{N}, 20^{\circ} 27^{\prime} \mathrm{E}\right)$, Serbia. In experimental conditions, the soil on which the experiment was set is cambisol with low percentage of humus $-2.27 \%$. The main characteristics of the soil at a depth of $0-30 \mathrm{~cm}$ were: texture: clay; $\mathrm{CaCO}_{3}: 0.83 \%$; $\mathrm{pH}$ in $\mathrm{KCl}: 6.1 ; \mathrm{K}_{2} \mathrm{O}$ : $14.7 \mathrm{mg} / 100 \mathrm{~g} ; \mathrm{P}_{2} \mathrm{O}_{5}: 1.6 \mathrm{mg} / 100 \mathrm{~g}$.

Before the terrain experiment was set up, the fertilization of commercial seeds of the 'Naki' variety was tested in laboratory conditions and the results obtained were in accordance with the $\approx 87 \%$ declaration. The weight of 1000 seeds of commercial seed of diploid variety 'Naki' was $2.14 \mathrm{~g}$. The terrain experiment was conducted according to a random block system in four repetitions on $10 \mathrm{~m}^{2}\left(5 \times 2 \mathrm{~m}^{2}\right)$ elementary plots. The diploid variety of perennial ryegrass used in the experiment is cv. 'Naki' and it was sown at the beginning of the experiment (2011) and seeds were collected and examined after each harvest for the next three years (2012, 2013 and 2014). The Perennial ryegrass was sown at four rows spacing $(12.5 ; 25 ; 37.5$ and $50 \mathrm{~cm})$ in autumn of 2011. The sowing rate used in the experiment was equivalent to 9, 16,23, $30 \mathrm{~kg} \mathrm{ha}^{-1}$ with the following amount of nitrogen fertilizer - $0,30,60,90 \mathrm{~kg} \mathrm{ha}^{-1}$. The observed factors were combined with each other and it was measured the impact of the factors on the production characteristics of perennial ryegrass.

Prior to the seed harvest, some biometric measurements were made such as the generative the height of the tiller, the length of the spike and the number of spikelets per spike based on 10 randomly sampled plants from each plot. The perennial ryegrass was harvested by sickle in the third decade of June and the first decade of July. Harvesting of the perennial ryegrass for all three years began when the gentle hand rubbing of the spines resulted in a visible breakage of the seeds. The tillers of perennial ryegrass were put in bunches and dried 
outdoors in a well-ventilated place. After free drying, the seeds were ground, cleaned and weighed. The straw was weighed as a dry mass.

\section{Statistical analysis}

Hence the harvest index was calculated using the formula $\mathrm{HI}=[\mathrm{SI} /(\mathrm{SI}+\mathrm{SDM}] \mathrm{k} 100$, where $\mathrm{HI}$ is the harvest index (\%), SI is the seed yield $\left(\mathrm{kg} \mathrm{ha}^{-1}\right)$, and SDM is the dry mass (straw yield) $\left(\mathrm{kg} \mathrm{ha}^{-1}\right)$ The data collected were sublimated, categorized by year and parameter and analysed using accurate statistical analyses (e.g., ANOVA) using the Statistical Package for the Social Sciences (SPSS) and Microsoft Excel 2016.

\section{Results}

Weather conditions were monitored from the nearest meteorological station in Smederevska Palanka (SP) in Serbia. They are shown by average values of monthly temperatures and monthly rainfall from September to August next year, which coincides with sowing and harvesting of seeds. Average monthly temperatures did not deviate significantly from the annual average between March and August (vegetative period). The exception was May, when in all three growing seasons the average was less than the average for the period 2005-2014. The rainfall regime during the 2011/2012 season has two noticeable periods: November March; within the month with the highest rainfall was January $(81.6 \mathrm{~mm})$ and the other period is April-June, with the highest rainfall being recorded in May $(117 \mathrm{~mm})$. The period between June and July is a period of drought, with rainfall and the temperature rising $\left(23.1\right.$ and $25.5{ }^{\circ} \mathrm{C}$, respectively). This indicates an unfavourable impact on seed maturation and seed expansion, which if prevented by intensive harvesting.

During the second experimental year (2012/2013), $117 \mathrm{~mm}$ of water sediment was registered in May, which causes intensification of weeds. The most important months for maturation and seed harvesting (June $49.6 \mathrm{~mm}$ and July $-74.1 \mathrm{~mm}$ ) were dry but also favourable for safe seed production. Temperature regime throughout the growing season was favourable, with temperatures increasing from March $\left(18.0^{\circ} \mathrm{C}\right)$ to June $\left(20.1{ }^{\circ} \mathrm{C}\right)$ and July $\left(22.5^{\circ} \mathrm{C}\right)$ which means that year was very good for seed production. The last vegetative season of 2013/2014. is characterized by the sum of rainfall during the vegetation period (March-August) which is twice as enormous than the average for ten years (2005-2014). In May, $238.2 \mathrm{~mm}$ of rainfall was recorded (Figure 1a; 1b).

In the last decade, research on grassland populations has focused on quantified production per unit area. Some plants have been observed as a minimal physiological unit in grassland components (Simić et al., 2009; Janković et al., 2018). The tillers are the basic unit of production and durability of the lawn (Matthev et al., 2011), so that to further improvement of production, the characteristics of the tillers are important for some species.
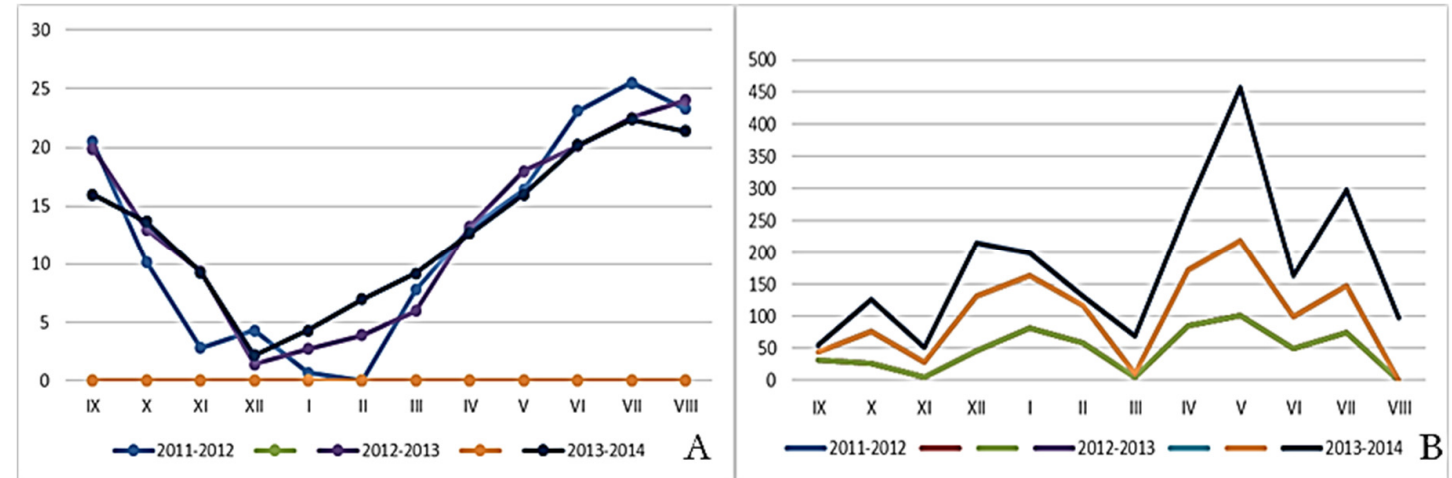

Figure 1. Description of average monthly temperatures

(A) and Description of total monthly precipitation; (B) in Smederevska Palanka, Serbia [2011-2014]. 
Table 1. Effect of inter-row spacing and seeding rate on tiller characteristics, 2012-2014

\begin{tabular}{|c|c|c|c|}
\hline Parameter & $\begin{array}{l}\text { Tiller length } \\
(\mathrm{cm})\end{array}$ & $\begin{array}{l}\text { Spike length } \\
(\mathrm{cm})\end{array}$ & $\begin{array}{l}\text { Spikelets per spike } \\
\quad\left(\text { no. tiller }{ }^{-1}\right)\end{array}$ \\
\hline Inter-row spacing, cm, A & \multicolumn{3}{|c|}{2012} \\
\hline 12.5 & $62.8^{\mathrm{c}^{*}}$ & $20.9^{c}$ & $19.7^{c}$ \\
\hline 25.0 & $66.3^{\mathrm{b}}$ & $21.9^{\mathrm{b}}$ & $22.0^{\mathrm{b}}$ \\
\hline 37.5 & $70.2^{\mathrm{a}}$ & $25.7^{\mathrm{a}}$ & $24.3^{a}$ \\
\hline 50.0 & $75.0^{\mathrm{a}}$ & $27.9^{\mathrm{a}}$ & $27.0^{\mathrm{a}}$ \\
\hline \multicolumn{4}{|l|}{ Seeding rate, $\mathrm{kg} \mathrm{ha}^{-1}, \mathrm{~B}$} \\
\hline 9 & $72.1^{a}$ & $25.6^{a}$ & $24.7^{\mathrm{a}}$ \\
\hline 16 & $71.3^{\mathrm{a}}$ & $25.4^{a}$ & $24.3^{\mathrm{a}}$ \\
\hline 23 & $65.6^{\mathrm{b}}$ & $22.8^{\mathrm{b}}$ & $22.2^{\mathrm{b}}$ \\
\hline 30 & $65.2^{\mathrm{b}}$ & $22.6^{\mathrm{b}}$ & $21.8^{\mathrm{b}}$ \\
\hline Average & 68.6 & 24.1 & 23.3 \\
\hline Inter-row spacing, cm, A & \multicolumn{3}{|c|}{2013} \\
\hline 12.5 & $67.7^{\mathrm{c}}$ & $25.2^{c}$ & $20.5^{\mathrm{c}}$ \\
\hline 25.0 & $70.1^{\mathrm{b}}$ & $29.0^{\mathrm{b}}$ & $23.5^{\mathrm{b}}$ \\
\hline 37.5 & $77.0^{\mathrm{a}}$ & $29.9^{\mathrm{a}}$ & $26.8^{\mathrm{a}}$ \\
\hline 50.0 & $83.8^{\mathrm{a}}$ & $35.4^{\mathrm{a}}$ & $28.9^{\mathrm{a}}$ \\
\hline \multicolumn{4}{|l|}{ Seeding rate, $\mathrm{kg} \mathrm{ha}^{-1}, \mathrm{~B}$} \\
\hline 9 & $78.1^{\mathrm{a}}$ & $31.2^{\mathrm{a}}$ & $26.1^{\mathrm{a}}$ \\
\hline 16 & $77.2^{\mathrm{a}}$ & $31.0^{\mathrm{a}}$ & $25.7^{\mathrm{a}}$ \\
\hline 23 & $71.8^{\mathrm{b}}$ & $28.8^{\mathrm{b}}$ & $24.0^{\mathrm{b}}$ \\
\hline 30 & $71.5^{\mathrm{b}}$ & $28.5^{\mathrm{b}}$ & $23.8^{\mathrm{b}}$ \\
\hline Average & 74.7 & 29.9 & 24.9 \\
\hline Inter-row spacing, cm, A & \multicolumn{3}{|c|}{2014} \\
\hline $12.5 \mathrm{~cm}$ & $60.8^{\mathrm{b}}$ & $22.3^{\mathrm{b}}$ & $16.9^{c}$ \\
\hline $25.0 \mathrm{~cm}$ & $60.0^{\mathrm{b}}$ & $22.6^{\mathrm{b}}$ & $18.6^{\mathrm{b}}$ \\
\hline $37.5 \mathrm{~cm}$ & $64.5^{\mathrm{a}}$ & $24.0^{\mathrm{a}}$ & $21.5^{\mathrm{a}}$ \\
\hline $50.0 \mathrm{~cm}$ & $68.7^{\mathrm{a}}$ & $24.7^{\mathrm{a}}$ & $22.4^{\mathrm{a}}$ \\
\hline \multicolumn{4}{|l|}{ Seeding rate, $\mathrm{kg} \mathrm{ha}^{-1}, \mathrm{~B}$} \\
\hline 9 & $68.8^{\mathrm{a}}$ & $24.7^{a}$ & $20.6^{a}$ \\
\hline 16 & $67.6^{a}$ & $24.6^{a}$ & $20.5^{a}$ \\
\hline 23 & $59.2^{\mathrm{b}}$ & $22.3^{\mathrm{b}}$ & $19.2^{\mathrm{b}}$ \\
\hline 30 & $58.4^{\mathrm{c}}$ & $21.9^{c}$ & $19.1^{\mathrm{b}}$ \\
\hline Average & 63.5 & 23.4 & 19.8 \\
\hline
\end{tabular}

${ }^{*}$ Notes (legend): Meanings in the columns followed by the same letter in the index are not significantly different according to Fisher's protected LSD values (LSD test, $\mathrm{p}<0.05$ ).

The highest and smallest height of tillers were recorded in $2013(74.7 \mathrm{~cm})$ and in $2014(63.5 \mathrm{~cm})$, respectively. Due to very wet conditions in 2014 (rainfall in the vegetative period was $710.9 \mathrm{~mm}$ and in 2013 it was $332.5 \mathrm{~mm}$ ), these two years were climatic extremes for the height of the tillers (Table 1).

Both the spacing and the rate of sowing had a greater effect on all components of seed yield than their interaction (Tables 2 and 3). The highest height of tiller was achieved by sowing the seed at wider row spacing in all three years linking with a higher sowing rate (seed rate); which without clear regularity is the result of greater use of nutrients and characteristics of location. Sowing in rows with narrower spacing had a greater impact on length of the spike in all three years, so the longest spike was measured in $2013(29.9 \mathrm{~cm})$, while the shortest spike was achieved in $2014(23.4 \mathrm{~cm})$, Table 1. 
Table 2. Effect of inter-row spacing and seeding rate on harvest characteristics, 2012-2014

\begin{tabular}{|c|c|c|c|}
\hline Parameter & $\begin{array}{c}\text { Seed yield } \\
\left(\mathrm{kg} \mathrm{ha}^{-1}\right)\end{array}$ & $\begin{array}{c}\text { Shoot DM } \\
\left(\mathrm{kg} \mathrm{ha}^{-1}\right)\end{array}$ & $\begin{array}{c}\text { Harvest index } \\
(\%)\end{array}$ \\
\hline Inter-row spacing, $\mathrm{cm}, \mathrm{A}$ & \multicolumn{3}{|c|}{2012} \\
\hline 12.5 & $443.2^{c^{*}}$ & $844.2^{\mathrm{a}}$ & $34.3^{\mathrm{c}}$ \\
\hline 25.0 & $454.3^{\mathrm{b}}$ & $808.0^{\mathrm{a}}$ & $36.0^{\mathrm{b}}$ \\
\hline 37.5 & $465.4^{\mathrm{a}}$ & $775.2^{\mathrm{b}}$ & $37.4^{\mathrm{a}}$ \\
\hline 50.0 & $485.2^{\mathrm{a}}$ & $729.7^{c}$ & $39.8^{\mathrm{a}}$ \\
\hline \multicolumn{4}{|l|}{ Seeding rate, $\mathrm{kg} \mathrm{ha}^{-1}, \mathrm{~B}$} \\
\hline 9 & $471.0^{\mathrm{a}}$ & $804.0^{\mathrm{a}}$ & $36.9^{a}$ \\
\hline 16 & $466.3^{\mathrm{a}}$ & $799.8^{\mathrm{a}}$ & $36.7^{\mathrm{b}}$ \\
\hline 23 & $455.8^{\mathrm{b}}$ & $776.8^{\mathrm{b}}$ & $36.9^{a}$ \\
\hline 30 & $455.0^{\mathrm{b}}$ & $776.3^{\mathrm{b}}$ & $36.9^{a}$ \\
\hline Average & 462.0 & 789.2 & 36.9 \\
\hline Inter-row spacing, $\mathrm{cm}, \mathrm{A}$ & \multicolumn{3}{|c|}{2013} \\
\hline 12.5 & $461.7^{c}$ & $881.4^{a}$ & $34.4^{c}$ \\
\hline 25.0 & $539.2^{c}$ & $840.5^{a}$ & $39.1^{\mathrm{b}}$ \\
\hline 37.5 & $594.5^{\mathrm{a}}$ & $807.2^{c}$ & $42.4^{a}$ \\
\hline 50.0 & $648.9^{\mathrm{a}}$ & $789.4^{c}$ & $45.1^{\mathrm{a}}$ \\
\hline \multicolumn{4}{|l|}{ Seeding rate, $\mathrm{kg} \mathrm{ha}^{-1}, \mathrm{~B}$} \\
\hline 9 & $572.1^{a}$ & $839.9^{a}$ & $40.4^{a}$ \\
\hline 16 & $569.4^{a}$ & $838.1^{\mathrm{a}}$ & $40.4^{a}$ \\
\hline 23 & $551.7^{\mathrm{c}}$ & $818.2^{\mathrm{b}}$ & $40.2^{a}$ \\
\hline 30 & $551.1^{\mathrm{c}}$ & $822.4^{\mathrm{b}}$ & $40.0^{\mathrm{b}}$ \\
\hline Average & 561.1 & 829.4 & 40.2 \\
\hline Inter-row spacing, cm, A & \multicolumn{3}{|c|}{2014} \\
\hline 12.5 & $208.4^{\mathrm{c}}$ & $972.2^{\mathrm{a}}$ & $17.5^{\mathrm{b}}$ \\
\hline 25.0 & $257.7^{\mathrm{c}}$ & $953.3^{\mathrm{a}}$ & $21.4^{\mathrm{b}}$ \\
\hline 37.5 & $309.0^{\mathrm{a}}$ & $896.5^{c}$ & $25.7^{\mathrm{a}}$ \\
\hline 50.0 & $343.7^{\mathrm{a}}$ & $878.1^{\mathrm{c}}$ & $28.2^{\mathrm{a}}$ \\
\hline \multicolumn{4}{|l|}{ Seeding rate, $\mathrm{kg} \mathrm{ha}^{-1}, \mathrm{~B}$} \\
\hline 9 & $293.9^{\mathrm{a}}$ & $955.0^{\mathrm{a}}$ & $23.6^{\mathrm{a}}$ \\
\hline 16 & $288.6^{a}$ & $951.9^{a}$ & $23.3^{\mathrm{a}}$ \\
\hline 23 & $268.5^{\mathrm{b}}$ & $897.3^{c}$ & $22.9^{b}$ \\
\hline 30 & $267.8^{\mathrm{b}}$ & $895.9^{c}$ & $22.9^{b}$ \\
\hline Average & 279.7 & 925.0 & 23.2 \\
\hline
\end{tabular}

${ }^{*}$ Notes (legend): Meanings in the columns followed by the same letter in the index are not significantly different according to Fisher's protected LSD values (LSD test, $\mathrm{p}<0.05$ ).

The number of spikelets per spike was also significantly influenced by the spacing between rows and sowing speeds, so that the best results are achieved at a wider spacing using the lowest seed rate. It is observed the same effect of humidity on the number of spikeletes per spike - the highest in 2013 ( 25 spikelets) and the lowest in 2014 (20 spikelets).

Dry weight (straw) accumulation was influenced by the way it was determined in the experiment. During all three years, it was a more constant parameter in relation to seed yield. The highest amount of dry weight was achieved in the last year - $2014\left(925.0 \mathrm{~kg} \mathrm{ha}^{-1}\right)$.

At the harvest, as an indicator of seed production efficiency, were influenced by all treatments applied. 
Table 3. Statistical summary of changes in tiller and harvest characteristics according to stand density (LSD test)

\begin{tabular}{|c|c|c|c|}
\hline Parameter & 2012 & 2013 & 2014 \\
\hline $\begin{array}{c}\text { Inter-row spacing } \mathrm{A} \\
\text { Seeding rate } \mathrm{B} \\
\mathrm{AxB}\end{array}$ & $\begin{array}{l}{ }^{* *} \\
{ }^{* *} \\
\mathrm{~ns}\end{array}$ & $\begin{array}{c}\text { Tiller length } \\
\qquad * * \\
* * \\
\text { ns }\end{array}$ & $\begin{array}{l}* * \\
* * \\
\text { ns }\end{array}$ \\
\hline $\begin{array}{c}\text { Inter-row spacing } \mathrm{A} \\
\text { Seeding rate } \mathrm{B} \\
\mathrm{AxB}\end{array}$ & $\begin{array}{l}* * \\
* * \\
\text { ns }\end{array}$ & $\begin{array}{c}\text { Spike length } \\
{ }_{* *} \\
* * \\
* *\end{array}$ & $\begin{array}{l}* * \\
* * \\
\text { ns }\end{array}$ \\
\hline $\begin{array}{c}\text { Inter-row spacing } \mathrm{A} \\
\text { Seeding rate } \mathrm{B} \\
\mathrm{AxB}\end{array}$ & $\begin{array}{l}{ }^{* *} \\
{ }^{* *} \\
\mathrm{~ns}\end{array}$ & $\begin{array}{c}\text { Spikelets per spike } \\
* * \\
* * \\
\text { ns } \\
\end{array}$ & $\begin{array}{l}* * \\
* * \\
\text { ns }\end{array}$ \\
\hline $\begin{array}{c}\text { Inter-row spacing } \mathrm{A} \\
\text { Seeding rate B } \\
\text { AxB }\end{array}$ & $\begin{array}{l}{ }^{* *} \\
{ }^{* *} \\
\mathrm{~ns}\end{array}$ & $\begin{array}{c}\text { Seed yield } \\
*_{* *} \\
* * \\
\text { ns }\end{array}$ & $\begin{array}{l}* * \\
* * \\
\text { ns }\end{array}$ \\
\hline $\begin{array}{c}\text { Inter-row spacing A } \\
\text { Seeding rate B } \\
\text { AxB }\end{array}$ & $\begin{array}{l}* * \\
* * \\
*\end{array}$ & $\begin{array}{c}\text { Shoot DM } \\
\text { ** } \\
* * \\
\text { ns }\end{array}$ & $\begin{array}{l}* * \\
* * \\
\text { ns }\end{array}$ \\
\hline $\begin{array}{c}\text { Inter-row spacing } \mathrm{A} \\
\text { Seeding rate } \mathrm{B} \\
\mathrm{AxB}\end{array}$ & $\begin{array}{l}{ }^{* *} \\
\mathrm{~ns} \\
\mathrm{~ns}\end{array}$ & $\begin{array}{c}\text { Harvest index } \\
\text { ** } \\
* * \\
* *\end{array}$ & $\begin{array}{l}* * \\
* * \\
* *\end{array}$ \\
\hline
\end{tabular}

The highest harvest index was recorded in 2013 (40.2\%), which was an unexpected result. To explain the harvest components more objectively, they can be compared to the yield components using correlation analysis. As follows, a very significant correlation was notices between the height of the tiller and seed rate $(\mathrm{r}=$ $0.839)$, the height of the tiller and harvesting tiller $(r=0.721)$. The length of the spike and number of spikelets per spike have lower impact on seed yield and dry weight. The harvest index negatively affected the correlation of dry weight in all three years, while the seeding rate on yield increased.

\section{Discussion}

During the period 2012-2014, the level of impact of row spacing and sowing norm on seed yield in the main role is determined by agro ecological conditions, temperature and rainfall.

In the spring of 2012, it was the optimum rainfall, the main monthly temperature was about average, but temperatures above average have a significant impact. Also, the wider row spacing $(37.5 \mathrm{~cm}$ and $50 \mathrm{~cm})$ and the lower seed rate in the sowing $\left(9 \mathrm{~kg} \mathrm{ha}^{-1}\right.$ and $\left.16 \mathrm{~kg} \mathrm{ha}^{-1}\right)$ had a significant impact on the length of the tiller. A significant impact of the treatment was also recorded in the length of spike and in the number of spikelets per spike. The treatments had an impact on seed yield and harvest index (wider sowing and lower seed rate in sowing), but have a significant impact t of narrow sowing $(12.5 \mathrm{~cm}$ and $25 \mathrm{~cm})$ on the dry weight of tillers.

During 2013, it was achieved the highest length of the tiller from all of three observed years $(74.7 \mathrm{~cm})$. It was recorded a significant effect of wider row spacing $(37.5 \mathrm{~cm}$ and $50 \mathrm{~cm})$ and lower seed rate $\left(9 \mathrm{~kg} \mathrm{ha}^{-1}\right.$ and $\left.16 \mathrm{~kg} \mathrm{ha}^{-1}\right)$ were observed. The dry weight tiller is decreasing with increasing spacing between rows as well as increasing seed yield. 
Recommended sowing norms (seed rate in sowing) and row spacing in Perennial ryegrass production indicate that the agro ecological state of the locality is an important factor in seed production (Vuckovic et al., 1999). The same authors assume that a lower sowing rate can have a positive impact on seed yield compared to a high sowing rate. Sowing in narrower rows has a positive impact on weed control (Paul-Praat, 1995). In some other research, it has been noticed that optimal seed yield is obtained by sowing seeds at mid-spacing (20-25 $\mathrm{cm})$ (Gatarić, 2005); but also, there are good results achieved with wide sowing. Perennial grass seed responds favorably to autumn sowing, but the amount of seed obtained was lower than the results obtained from sowing in the mix (Szczepanek et al., 2004). Also, in the interaction between five sowing norms (1.4; 2.8; 5.6; 8.4; and $\left.11.2 \mathrm{~kg} \mathrm{ha}^{-1}\right)$ and three rows spacing $(10.2 ; 20.3$; and $30,5 \mathrm{~cm})$ placed in a random block with 4 repetitions, it was observed that a larger seed rate with sowing a wider row gives better results (Koeritz, 2012).

The results show that rainfall and the main monthly sum of temperatures in the last year (2014) have a significant impact on all treatment components. High rainfall over two successive years in months important for seed production led to abundant biomass accumulation (Simić et al., 2009) in the third year. It has also been noted that there was no interaction between the impact on seed yield and dry weight (except in 2012). Also, it has been observed that the seed rate lost crops in combination with climatic conditions.

Climate change has the potential to both positively and negatively affect the location, timing, and productivity of crop at local, national, and global scales (Popović, 2015; Mihailović et al., 2020). Climate and climate change are a particular challenge to the law, because the global characteristic of the impact of climate on the life of the entire planet creates the need for cooperation and commitment at international, regional and national levels. The right to a healthy environment belongs to the modern human rights corps. Environmental law as a whole, and in particular the section on climate change, presents a complex challenge in various professional and scientific fields. The right of its instruments should help and improve solutions for overcoming the negative consequences of the complex problem of contemporary civilization in the field of climate change (Jovanović and Mihailović, 2020).

Heavy rains in the spring of 2014 reduced the stock of photo-assimilates for seed development (Griffith, 2000). Growth of dry weight of tillers followed by a decreasing in seed yield and harvest index results in differences between 2013 and 2014 as a consequence of environmental tolerance.

\section{Conclusions}

During the tested period, the level of impact of row spacing and sowing norm on seed yield in the main role is determined by temperature and precipitation. Therefore, it can be concluded that the length of the tiller, the length of the spike and the number of spikelets per spike give better results by sowing in wider rows at 37.5 and $50 \mathrm{~cm}$ apart, using lower seed rate in the sowing $\left(9\right.$ and $\left.16 \mathrm{~kg} \mathrm{ha}^{-1}\right)$. Seed yield, the harvest index, also responds favourably to sowing in wider rows $(37.5$ and $50 \mathrm{~cm})$ with lower seed rate $\left(9\right.$ and $\left.16 \mathrm{~kg} \mathrm{ha}^{-1}\right)$. The resulting amount of straw (dry weight) was larger by sowing in narrow rows $(12.5 \mathrm{~cm})$, with lower seed rate $(9$ and $\left.16 \mathrm{~kg} \mathrm{ha}^{-1}\right)$.

\section{Authors' Contributions}

In this research, all authors contributed effectively. Conceptualization, resources, methodology; Formal analysis and writing original draft: MJT, SV, MI and VP; Designed the experiments; Supervision; Writing review and editing: SJ, VS, VL and AM. All authors read and approved the final manuscript. 


\section{Acknowledgements}

This research is part of the project 46006 "Sustainable Agriculture and Rural Development in Functioning of the Strategic Objectives of the Republic of Serbia in the Danube Region" and this paper is part of the projects, Grant numbers: 451-3-68/2020-14/200189 and 200032 and 200045, financed by the Ministry of Education, Science and Technology Development of Republic of Serbia; and Bilateral Project Serbia MNO 2019-2020: Alternative cereals and oil crops as a source of healthcare food and an important raw material for the production of biofuel.

The hereby work was accepted and presented at the GEA (Geo Eco-Eco Agro) International Conference 28 May 2020, Podgorica, Montenegro, and it has been published as abstract in "Book of Abstracts" (http://www.gea.ucg.ac.me/page.php?id=64).

\section{Conflict of Interests}

The authors declare that there are no conflicts of interest related to this article.

\section{References}

Bojović R, Popović V, Ikanović J, Živanović Lj, Rakaščan N, Popović S, ... Simić D (2019). Morphological characterization of sweet sorghum genotypes across environments. The Journal of Animal and Plant Sciences 29(3):721-729.

Bolaric S, Barth S, Melchinger AE, Posselt UK (2005). Genetic diversity in European perennial ryegrass cultivars investigated with RAPD markers. Plant Breeding 124:161-166. https://doi.org/10.1111/j.14390523.2004.01032.X

Cattani DJ (2007). Perennial ryegrass seed production. Agriculture, Food and Rural Initiatives Crops Knowledge Centre, Carman MB, Canada, pp 1-6.

Dalton SJ, Bettany AJE, Timms E, Morris P (1998). Co-transformed, diploid Lolium perenne (perennial ryegrass), Lolium multiflorum (Italian ryegrass) and Lolium temulentum (darnel) plants produced by micro-projectile bombardment. Plant Cell Reports 18:721-726. https://doi.org/10.1007/s002990050649

Fisakov M (1984). Influence of the way of sowing, of the quantity and time of fertilization with nitrogen on the yield of cocks-foot seed (Dactylis glomerata L.). Arhiv za Poljoprivredne Nauke (Yugoslavia).

Frame J (1989). Herbage productivity of a range of grass species under silage cutting regime. Grass and Forage Science 44:267-276. https://doi.org/10.1111/j.1365-2494.1989.tb02164.x

Gatarić Đ (2005). Seed farming with the basics of breeding. Faculty of Agriculture, University of Banja Luka. 1-377.

Griffith SM (2000). Changes in dry matter, carbohydrate and seed yield resulting from lodging in three temperate grass species. Annals of Botany 85:675-680. https://doi.org/10.1006/anbo.2000.1125

Grime JP, Hodgson JG, Hunt R (1988). Comparative plant ecology. Unwin Hyman Ltd, London, UK. http://www.gardenorganic.org.uk/organicweeds

Janković V, Vučković S, Mihailović V, Popović V, Živanović Lj, Simić D, ... Stevanović P (2018). Assessment of some parameters productivity and quality of populations Phleum pratense(L.) grown in conditions of Serbia. Genetika 50(1):1-10. https://doi.org/10.2298/GENSR1801001J

Jamil M, Hussain SS, Amjad Qureshi M, Mehdi SM, Nawaz MQ (2017). Impact of sowing techniques and nitrogen fertilization on castor bean yield in salt affected soils. The Journal of Animal \& Plant Sciences 27(2):451-456.

Jovanović Lj, Mihailović A (2020). Environmental protection: right and obligation. Gea International Conference 2020, Podgorica, Montenegro, pp 190-199.

Koeritz E (2012). Perennial ryegrass seed production in Minnesota: the effect of seeding rate, row spacing, and nitrogen on yield, agronomic characteristics, and stem rust. ASA, CSSA and SSSA Annual Meetings, Cincinnati, OH.

Kubik C, Sawkins M, Meyer W, Gaut B (2001). Genetic diversity in seven perennial ryegrass (Lolium perenne L.) cultivars based on SSR markers. Crop Science Journal 41:1565-1572. https://doi.org/10.2135/cropsci2001.4151565x 
Lakić Ž, Glamočlija Đ, Kondic D, Popović V, Pavlović S (2018). Forage plants and cereals in the function of soil protection from degradation. Monograph. Faculty of Agriculture, Banja Luka, Bosnia and Hercegovina pp 1-403.

Lakić Ž, Stanković S, Pavlović S, Krnjajic S, Popović V (2019). Genetic variability in quantitative traits of field pea (Pisum sativum L.) genotypes. Czech Journal of Genetics and Plant Breeding 55(1)1-7. https://doi.org/10.17221/89/2017-CJGPB

Matthew C, Sackville Hamilton NR (2011). Analyzing persistence of grass swards in terms of tiller birth and death. Pasture Persistence-Grassland Research and Practice Series 15:63-68.

Mihailović A, Jovanović Lj, Rajičić V (2020). Climate change as a threat to global economy. Gea International Conference 2020, Podgorica, Montenegro, pp 190-199.

Paul-Praat J (1995). Row spacing and seeding rate interaction in perennial ryegrass and tall fescue swards established by direct drilling (no-tillage). Massey University, Palmerston North, New Zealand pp 271-272.

Popović V (2015). The concept, classification and importance of biological resources in agriculture. In: Đorđević S, Milovanović J, Dražić G (Eds). Conservation and enhancement of biological esources in the service of ecoremediation. Monograph. Belgrade, pp 29-51.

Simić A, Vučković S, Maletić R, Sokolović D, Đorđević N (2009). The impact of seeding rate and interrow spacing on Italian ryegrass for seed in the first harvest year. Turkish Journal of Agriculture and Forestry 33(5):425-433.

Sokolović D, Babić S, Radović J, Milenković J, Lugić Z, Anđelković S, Vasić T (2012). Genetic variations of root characteristics and deep root production in perennial ryegrass cultivars contrasting in field persistency. In: Breeding strategies for sustainable forage and turf grass improvement Springer, Dordrecht pp 275-281.

Szczepanek M, Skinder Z (2004). Effect of the sowing method, date and row spacing on the yielding of Stadion perennial ryegrass [Lolium perenne L.] cultivated for seed. Electronic Journal of Polish Agricultural Universities. Series Agronomy 7(2).

Tomić Z, Sokolović D (2007). Breeding of perennial grasses - methods, criteria and results in Serbia. Zbornik Radova Instituta za Ratarstvo i Povrtarstvo 44(1):51-69.

Uzun A, Acikgoz E (1998). Effect of sowing season and seeding rate on the morphological traits and yield in pea cultivars of differing leaf types. Journal of Agronomy and Crop Science 181:215-222. https://doi.org/10.1111/j.1439037X.1998.tb00420.x

Vučković S, Petrović M, Mladenović G (1999). The effect of the way and sowing density on seed yield of perennial fodder grass and legumes. Selekcija i Semenarstvo 6(3-4):87-93.

Vučković S, Nedić M, Zarić D, Živanović LJ (1998). The effect of the way and sowing density on seed yield and seed germination of perennial ryegrass (Lolium perenne L.) in Western Srem. Contemporary Agriculture 47:65-68.
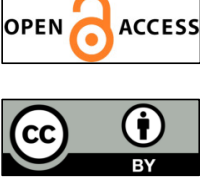

The journal offers free, immediate, and unrestricted access to peer-reviewed research and scholarly work. Users are allowed to read, download, copy, distribute, print, search, or link to the full texts of the articles, or use them for any other lawful purpose, without asking prior permission from the publisher or the author.

License - Articles published in Notulae Botanicae Horti Agrobotanici Cluj-Napoca are Open-Access, distributed under the terms and conditions of the Creative Commons Attribution (CC BY 4.0) License.

(c) Articles by the authors; UASVM, Cluj-Napoca, Romania. The journal allows the author(s) to hold the copyright/to retain publishing rights without restriction. 